\title{
Growth of sweet basil depending on nitrogen and potassium doses
}

\author{
Sylvana N Matsumoto ${ }^{1}$; Germano da S Araujo ${ }^{1}$; Anselmo Eloy S Viana ${ }^{2}$ \\ 'UESB, Lab. Fisiologia Vegetal, C. Postal 95, 45100-000 Vitória da Conquista-BA; gsaaraujo2000@yahoo.com.br; snaomi@uesb.edu.br; \\ ${ }_{2}^{2}$ UESB-Lab. Prod. Melhoramento Vegetal; aviana@gmail.com.br
}

\begin{abstract}
The objective of this study, carried out from October to December 2006, was to analyze the effects of increasing doses of nitrogen $(\mathrm{N})$ and potassium $(\mathrm{K})$ as well as the interaction between these elements on the growth of sweet basil plants cultivated under field conditions. The experimental design was split plots, holding in the main plots the $\mathrm{N}$ doses and in the subplots the $\mathrm{K}$ rates. Doses of 0, 50, 100 and 150 $\mathrm{kg} \mathrm{ha}^{-1}$ were established for $\mathrm{N}$ and $\mathrm{K}$, applied as urea and potassium chloride, respectively. The seedlings were transplanted to beds, in $40 \mathrm{x}$ $30 \mathrm{~cm}$ spacing, and each plot had 24 plants. The evaluations at 45 days after transplanting detected no effect of $\mathrm{N}$ levels in stem diameter, Spad index and number of internodes. A quadratic polynomial model was defined for the relationship between $\mathrm{N}$ rates and the referred characteristics. A NK interaction for total leaf area was observed, indicating that, on the absence of $\mathrm{K}$ fertilization, increasing $\mathrm{N}$ doses resulted in higher total leaf area. Higher doses of $\mathrm{N}$ decreased total leaf area of plants under greater $\mathrm{K}$ doses.
\end{abstract}

Keywords: Ocimum basilicum, macronutrients.

\section{RESUMO}

Crescimento de manjericão doce em função de doses de nitrogênio e potássio

Objetivou-se, neste estudo, realizado no período de outubro a dezembro de 2006, no campo experimental e no Laboratório de Fisiologia Vegetal da Universidade Estadual do Sudoeste da Bahia, verificar os efeitos de doses crescentes de nitrogênio $(\mathrm{N})$ e potássio (K), bem como da interação entre estes elementos no crescimento de plantas de manjericão doce, cultivadas em condição de campo. $\mathrm{O}$ delineamento experimental foi parcelas subdivididas, estando na parcela as doses de $\mathrm{N}$ e nas subparcelas as doses de K. Foram estabelecidas doses de 0,50, 100 e $150 \mathrm{~kg} \mathrm{ha}^{-1}$ para $\mathrm{Ne} \mathrm{K}$, aplicados na forma de uréia e cloreto de potássio, respectivamente. O plantio das mudas foi realizado em canteiros, em espaçamentos de 40 × 30 $\mathrm{cm}$. A parcela constou de 24 plantas. Aos 45 dias após o transplantio verificou-se efeito das doses de $\mathrm{N}$ sobre o diâmetro do caule, índice Spad e número de internódios. Para a relação entre as doses de $\mathrm{N}$ e as referidas características foi definido o modelo polinomial quadrático. Verificou-se interação entre $\mathrm{N}$ e K para área foliar total, indicando que, sob ausência de adubação potássica, doses crescentes de $\mathrm{N}$ induziram aumento da área foliar. Com elevadas doses de $\mathrm{N}$, houve redução da área foliar sob doses crescentes de K.

Palavras-chave: Ocimum basilicum, macronutrientes.

(Recebido para publicação em 13 de julho de 2012; aceito em 5 de julho de 2013)

(Received on July 13, 2012; accepted on July 5, 2013)

$\mathrm{N}$ owadays, discussions about fertilizer sources are constituted by a diverse range of viewpoints, in many times, divergent. According to Malik et al. (2011), the planting of medicinal herbs under integrated management with organic and inorganic fertilizers is the best current strategy that can be employed to improve yield and the active compounds of these plants. However, in many situations, the high cost of nutrient sources and the difficulty to supply the necessary amount of organic manure makes the conventional management the best strategy to produce herbs.

Biesiada \& Kus (2010) verified a straight relation on the growth of basil and macroelements accumulation with irrigation and $\mathrm{N}$ doses. In the referred study it was verified that the highest quantities of phosphorus and magnesium were obtained at nitrogen dose of $150 \mathrm{~kg} \mathrm{ha}^{-1}$ while the highest values of potassium and calcium were verified at $250 \mathrm{~kg} \mathrm{ha}^{-1}$ of $\mathrm{N}$.

For basil planting, Prakasa Rao et al. (2007) verified that elevated $\mathrm{N}$ availability (doses over $100 \mathrm{~kg} \mathrm{ha}^{-1}$ ) and $\mathrm{K}$ (doses over $80 \mathrm{~kg} \mathrm{ha}^{-1}$ ) resulted in higher plant yield and essential oil content. Alizadeh et al. (2010) verified a high correlation between shoot dry mass in relation to total dry matter weight, essential oils content, extraction efficiency of essential oils and phenolic compounds content of basil plants.

The increasing nitrogen doses caused the increase of dry matter, ammonium and nitrate nitrogen, potassium and protein contents (Nurzynska-Wierdak et al., 2011). The increasing potassium doses contributed to elevation of protein and total nitrogen concentration, as well as to the decrease of ammonium and nitrate nitrogen contents in basil herb.

According to Tsay et al. (2011), NK interaction is a very sophisticated phenomenon and occurs at many levels of plant metabolism, having an excluding effect between these elements on the mechanisms of absorption. There are many similarities between $\mathrm{NH}_{4}^{+}$and $\mathrm{K}^{+}$ions including charge, hydration status and size, suggesting the existence of a sharing in membrane transport component. This fact was verified by the effect of $\mathrm{NH}_{4}^{+}$ions in blocking $\mathrm{K}^{+}$transport systems (Qi et al., 2008). Szczerba et al. (2008a, 2008b) observed on rice and barley plants that an elevated $\mathrm{K}$ concentration restricted the movement of $\mathrm{NH}_{4}^{+}$, reducing the flux rate in relation to influx and, by this way, minimizing the toxic effects of $\mathrm{NH}_{4}^{+}$, avoiding an excessive accumulation. 
To achieve a more comprehensive and conclusive response about this theme it is necessary to built of a knowledge basis from specific studies, which must be realized under conditions that respect the main branches of scientific tendencies and a wide range of biotic and abiotic factors that characterize the Brazilian territory.

The aim in this study was to verify the effect of increasing doses of $\mathrm{N}$ and $\mathrm{K}$, as well as the interaction between these elements on vegetative growth of sweet basil.

\section{MATERIAL AND METHODS}

A field experiment was carried out from October to December, 2006, in field at the Universidade Estadual do Sudoeste da Bahia, Vitória da Conquista, Bahia state, Brazil (1451'58'S, 4050'22'W, $928 \mathrm{~m}$ altitude). During the study period, total rainfall was $421.1 \mathrm{~mm}$, with highest rate occurring in November $(252.7 \mathrm{~mm})$, maximum monthly temperature showed variations between 26.1 and $27.4^{\circ} \mathrm{C}$, with minimum temperatures ranging from 17.3 to $18^{\circ} \mathrm{C}$. Relative humidity was monthly measured at 12,18 and 24 hours, ranging from 76-78, 66-67, $89-92 \%$, respectively. The soil was classified as Alic to moderate Yellow Latosol with loamy clay texture having the following characteristics, according to soil chemical analysis at $0-20 \mathrm{~cm}$ depth: $\mathrm{pH}($ water $)=6.5 ; \mathrm{P}($ Mehlich $)=$ $4.0 \mathrm{mg} \mathrm{dm}^{-3} ; \mathrm{K}^{+}=0.36 \mathrm{cmol} \mathrm{dm}^{-3} ; \mathrm{Ca}^{2+}=$ $4.6 \mathrm{cmol} \mathrm{dm}^{-3} ; \mathrm{Mg}^{2+}=1.6 \mathrm{cmol}_{\mathrm{c}} \mathrm{dm}^{-3}$; $\mathrm{Al}^{3+}=0,00 \mathrm{cmol}_{\mathrm{c}} \mathrm{dm}^{-3} ; \mathrm{H}^{+} \mathrm{Al}=1.6 \mathrm{cmol}_{\mathrm{c}}$ $\mathrm{dm}^{-3} ; \mathrm{SB}=6.6 \mathrm{cmol}_{\mathrm{c}} \mathrm{dm}^{-3} ; \mathrm{T}=8.2 \mathrm{cmol}_{\mathrm{c}}^{\mathrm{c}}$ $\mathrm{dm}^{-3} ; \mathrm{V}=80 \%$. Planting was carried out plowing, harrowing and making the beds, where foundation fertilization was applied with simple superphosphate (18 $\mathrm{g} \mathrm{m}^{-2}$ ). Supplementary irrigation and hand weeding were done during all time of vegetative growth.

The experiment was arranged in a split plot design, with three replications. The $\mathrm{N}$ doses were a factor of major plots and $\mathrm{K}$ doses were considered as a factor of secondary plots. For both factors, doses of $0,50,100$ and $150 \mathrm{~kg}$ $\mathrm{ha}^{-1}$ were applied in two steps, at 9 and 24 days after transplanting date. The $\mathrm{N}$ and $\mathrm{K}$ sources were respectively urea and potassium chloride, distributed over the bed surface. Sweet basil seeds were sown in trays constituted by 100 cells, and at the stage of three pairs of leaves, the seedlings were planted to the beds. At this stage, seedlings were arranged in a $2.88 \mathrm{~m}^{2}(1.2 \times 2.4 \mathrm{~m})$ experimental unit performing 24 plants, cropped in $30 \times 40 \mathrm{~cm}$, considering eight central plants to be sampled in each evaluation.

At the end of the vegetative cycle, 45 days after transplanting, growth characteristics (plant height, stem diameter, number of internodes, number of plagiotropic branches, canopy leaf area and above-ground dry mass) and leaf Spad index were evaluated.

Data were submitted to analysis of variance and mathematical models were adjusted according to " $F$ " test at 1, 5 and $10 \%$ significance level, determination coefficient (greater than 50\%) and the biological phenomenon. The software used was SAEG, version 9.1.

\section{RESULTS AND DISCUSSION}

$\mathrm{N}$ rates promoted alterations in stem diameter, number of internodes and Spad

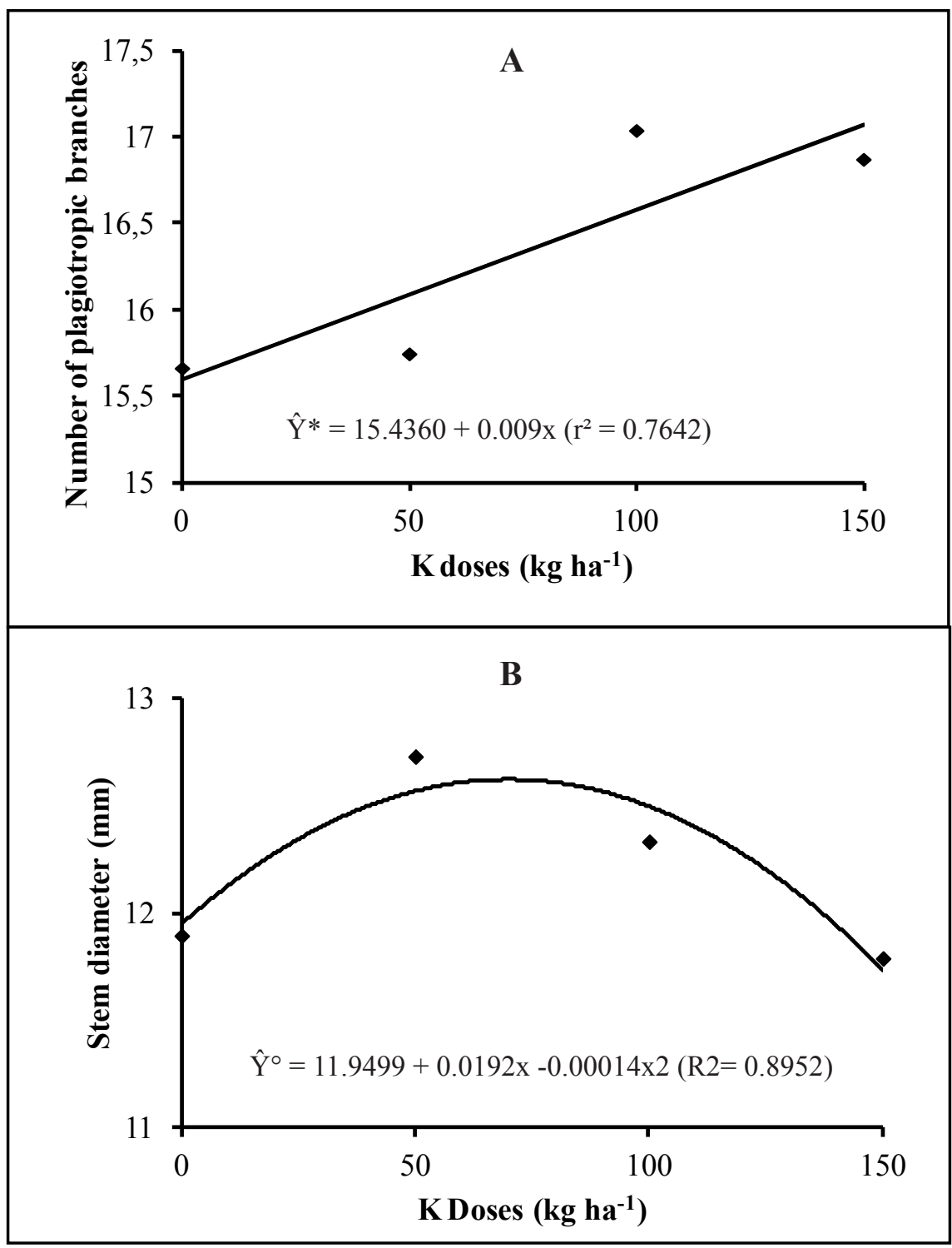

Figure 1. Number of plagiotropic branches (A) and stem diameter (B) of basil plants (Ocimum basilicum) grown in field condition, under different doses of nitrogen and potassium fertilization, at 45 days after transplanting [número de ramos plagiotrópicos (A) e diâmetro de caule (B) de plantas de manjericão (Ocimum basilicum) cultivadas em campo sob diferentes doses de nitrogênio e potássio aos 45 dias após transplantio]. ( ${ }^{*},{ }^{\circ}$ Significant at 1 and $5 \%$ probability, respectively, by $\mathrm{F}$ test).Vitória da Conquista, UESB, 2006. 


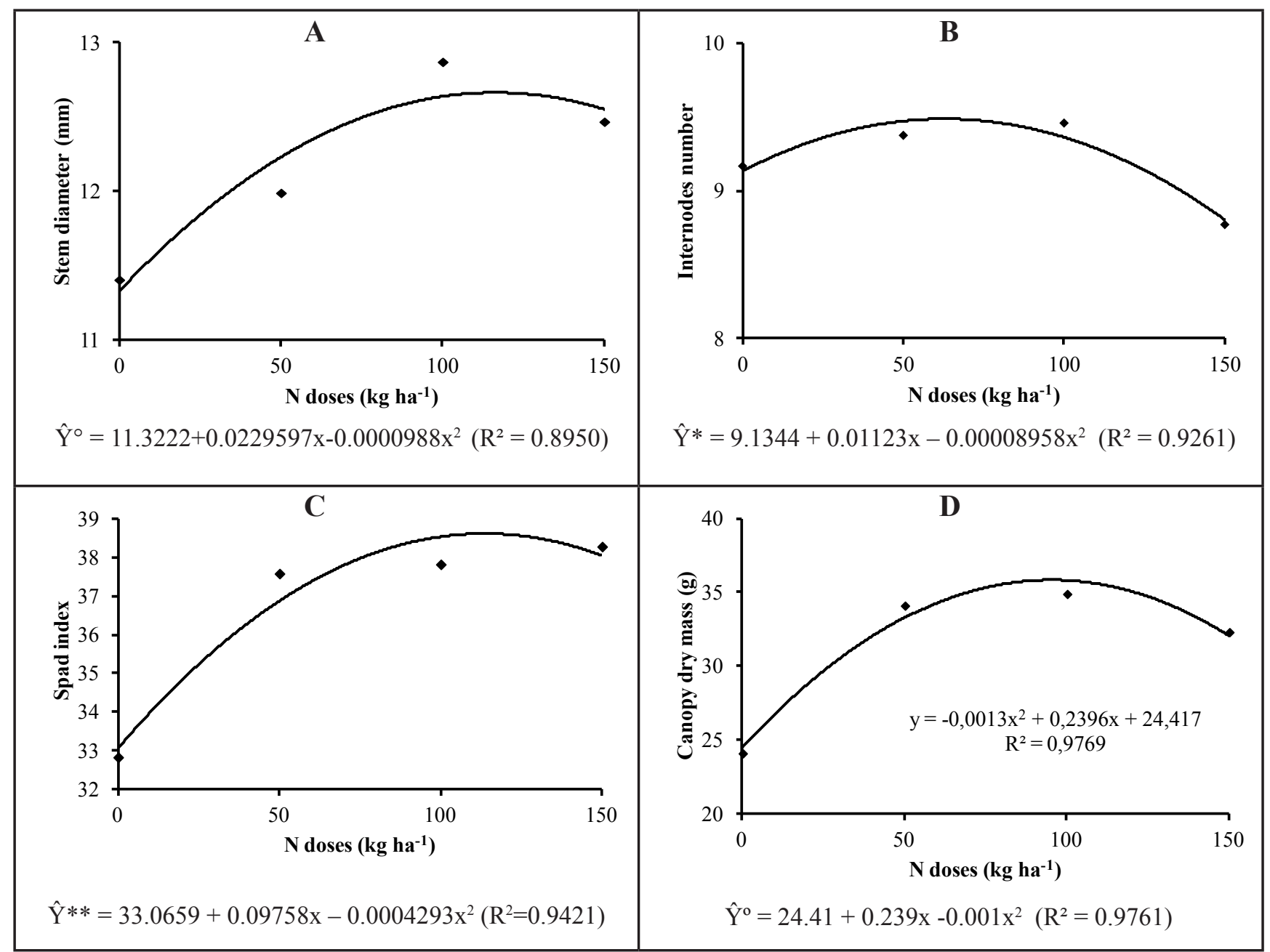

Figure 2. Stem diameter (A), number of internodes (B), Spad index(C) and above-ground dry weight (D) of basil plants (Ocimum basilicum) grown in field conditions under different doses of Nitrogen and Potassium fertilization, at 45 days after transplanting [diâmetro de caule (A), número de internodios (B), índice Spad (C) e peso seco da parte aérea de plantas (D) de manjericão (Ocimum basilicum) cultivadas em condição de campo sob diferentes doses de nitrogênio e potássio aos 45 dias após transplantio]. ( ${ }^{*}{ }^{\circ}$ Significant at 1 and $5 \%$ probability, respectively, by F test). Vitória da Conquista, UESB, 2006.

index; the interaction between $\mathrm{N}$ and $\mathrm{K}$ was verified only on leaf area. Although no effect of $\mathrm{K}$ was observed for any evaluated characteristics, according to variance analysis of the regression, it was defined a tendency of number of plagiotropic branches and stem diameter relative to $\mathrm{K}$ doses (Figure 1).

The relationship between $\mathrm{K}$ doses and number of plagiotropic branches was outlined by an increasing linear model and, to relationship between $\mathrm{K}$ doses and stem diameter, a quadratic polynomial model was defined (Figure 1 A). Camargo et al. (2008), in studies of Aster ericoides, found that $\mathrm{K}$ fertilization did not affect number of branches. According to Rubio et al. (2008), K availability can affect auxin accumulation, by means of reduced expression of gene that controls this hormone biosynthesis. For this study, the trend of increasing $\mathrm{K}$ doses promoting higher number of plagiotropic branches was related to the restriction of apical dominance. So, indirectly, some indications were verified that the increasing of $\mathrm{K}$ doses reduces the auxin action promoting an apical dominance phenomenon with consequent reduction of plagiotropic branches.

The turning point of established model for the relationship between stem diameter and $\mathrm{K}$ reached a maximum of $12.61 \mathrm{~mm}$ at a dose of $68.57 \mathrm{~kg} \mathrm{ha}^{-1}$ of $\mathrm{N}$ (Figure 1B). The increase in stem diameter was reported by Costa et al. (2008) and it was related to a higher transport capacity of Ocimum selloi plants cultivated under different organic fertilization. It should be considered that the absorption and assimilation of both $\mathrm{K}$ and $\mathrm{N}$ by species and cultivars might vary according to genotypic factor. In studies realized by Nguyen et al. (2010), Dark Opal cultivar showed greater K rates in leaves in relation to Genovese and Sweet Tai.

Jaćimović et al. (2010) found no effect of increasing $\mathrm{N}$ doses on shoot and leaf dry mass of sweet basil. However, a striking difference to height and number of flowers was observed among four varieties evaluated (Obični, Organski, Purpurni, and Patul-jasti). Sifola \& Barbieri (2006) verified that applying $\mathrm{N}$ doses (ranging between 0 to $300 \mathrm{~kg}$ $\mathrm{ha}^{-1}$ ) resulted in a dry weight rise of above-ground part. Higher values of leaf fresh weight and number of leaves of 


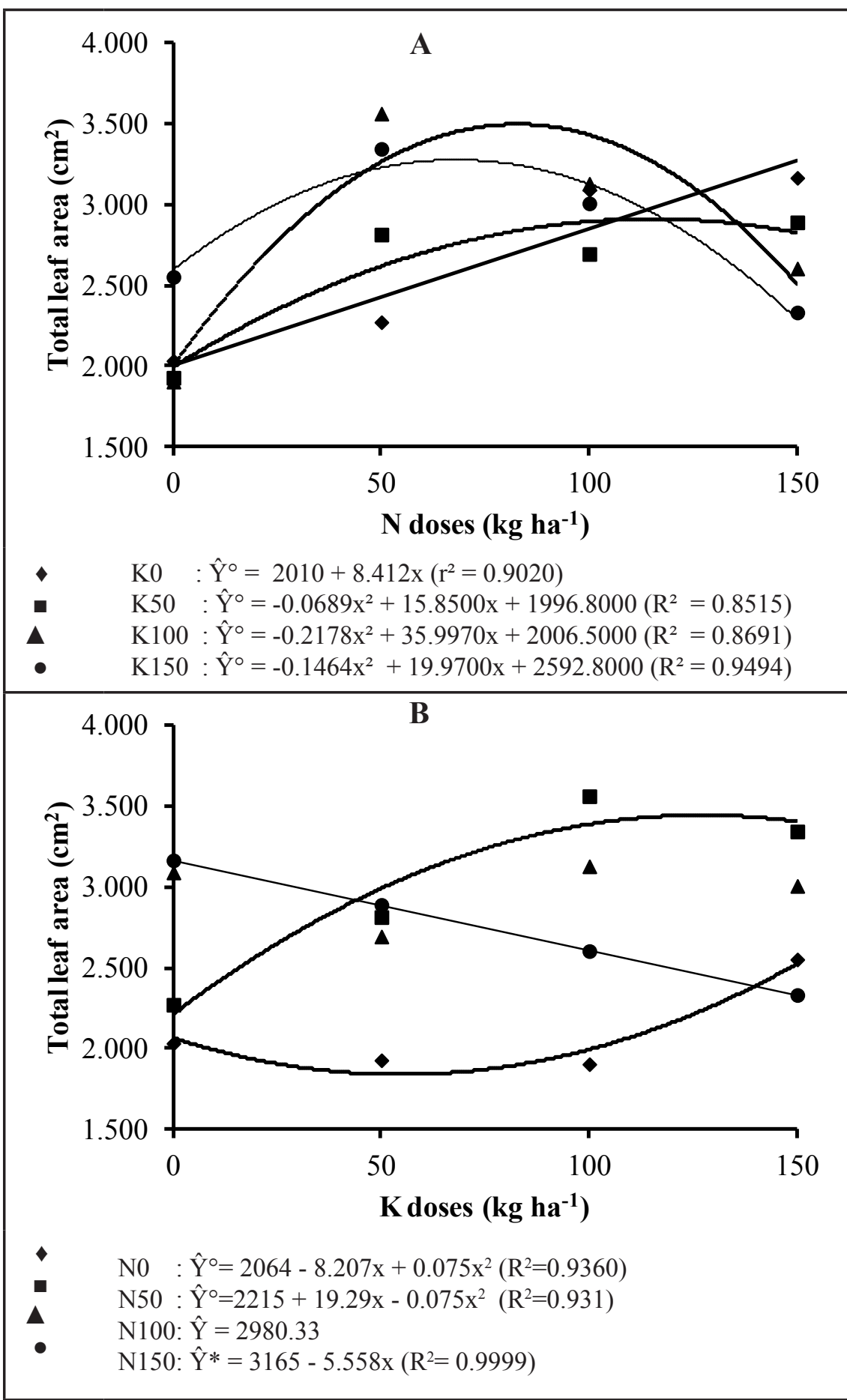

Figure 3. Total leaf area of basil plants (Ocimum basilicum) grown in field conditions, under different doses of nitrogen and potassium fertilization, at 45 days after transplanting [area foliar total de plantas de manjericão (Ocimum basilicum) cultivadas em campo sob diferentes doses de nitrogênio e potássio após 45 dias do transplantio]. (*, ${ }^{\circ}$ Significant at 1 and $5 \%$ probability, respectively, by F test). Vitória da Conquista, UESB, 2006.

lettuce cultivars Mostruoso Mammouth and Napoletano were observed in the referred study, in comparison to Genovese Profumatissimo.

For $\mathrm{N}$ effect, a quadratic polynomial model was designed for stem diameter (Figure 2A), number of internodes (2B), achieved in $61.11 \mathrm{~kg} \mathrm{ha}^{-1} \mathrm{~N}$.

In a study about $\mathrm{N}$ fertilization in sweet basil planting, Golcz et al. (2006) verified that intermediate doses of 1.2 $\pm 0.6 \mathrm{~g} \mathrm{~N}$ plant $^{-1}$ resulted in a higher leaf chlorophyll level. At higher doses, a decreasing value of chlorophyll was observed, similar to that occurred in the present study. Despite the absence of $\mathrm{N}$ effects on chlorophyll, carotenoids and anthocyanins rates of basil plants, Politycka \& Golcz (2004) observed a positive correlation between increasing doses of $\mathrm{N}$ and chloroplastidic pigments, with higher coefficients of chlorophyll $\mathrm{b}$ and carotenoids.

According to Sharafzadeh \& Alizadeh (2011) it was verified that a greater accumulation of shoot dry mass occurred when highest doses of NPK were applied (150, 100 and $100 \mathrm{~kg} \mathrm{ha}^{-1}$, respectively). Souza et al. (2007) observed, for mint hydroponic cultivation, that greater $\mathrm{N}$ concentrations $\left(120 \mathrm{mg} \mathrm{L}^{-1}\right)$ resulted in a higher above-ground plant biomass. According to Zheljazkov et al. (2008), the relationship between $\mathrm{N}$ rates and basil plants growth was characterized by quadratic polynomial model, the highest values being reached at approximately $60 \mathrm{~kg} \mathrm{ha}^{-1} \mathrm{~N}$. Biesiada \& Kuś (2010) observed that $150 \mathrm{~kg} \mathrm{ha}^{-1}$ of $\mathrm{N}$ favored $\mathrm{P}$ and $\mathrm{Mg}$ accumulation and higher $\mathrm{Ca}$ and $\mathrm{K}$ rates were verified on basil plants submitted to $250 \mathrm{~kg} \mathrm{ha}^{-1}$ of $\mathrm{N}$, resulting in a greater production. According to Sifola \& Barbieri (2006), the higher rates of fresh mass of basil occurred in $300 \mathrm{~kg} \mathrm{ha}^{-1}$ of $\mathrm{N}$ fertilization. In studies about $\mathrm{N}$ applying in basil hydroponic cultivation, Gonzalez-Garcia et al. (2009) verified that $\mathrm{NH}_{4}^{+} / \mathrm{NO}_{3}{ }^{-}$ratio of $20 / 80$ promoted the greatest height, leaf area and biomass accumulation.

The NK interaction was observed to total leaf area, and the establishment of all doses of evaluated elements was possible, except for $100 \mathrm{~kg} \mathrm{ha}^{-1}$ of $\mathrm{K}$ in function to $\mathrm{N}$ doses (Figure 3). For range of $\mathrm{N}$ rates at each $\mathrm{K}$ dose, it was possible to establish models of behavior trend (Figure 3A). The increasing linear model was defined to $0 \mathrm{~kg} \mathrm{ha}^{-1}$ of $\mathrm{K}$ dose as a function to $\mathrm{N}$ doses, with occurrence of greater value of leaf area to $150 \mathrm{~kg}$ $\mathrm{ha}^{-1}$. The quadratic polynomial model 
was outlined for other doses of $\mathrm{K}$, with maximum turning point observed in doses of 115.86 and $59 \mathrm{~kg} \mathrm{ha}^{-1}$ of $\mathrm{N}$. Therefore, despite of the absolute value of the total leaf area, it was observed that the interaction between $\mathrm{N}$ and $\mathrm{K}$ was characterized by requirement of lower concentrations of $\mathrm{N}$ as a function of increasing doses of $\mathrm{K}$. A less expressive, but equally important condition occurred for relation between $\mathrm{K}$ doses and each $\mathrm{N}$ doses, being defined the quadratic polynomial model for 0 and $50 \mathrm{~kg} \mathrm{ha}^{-1}$ and a linear model for 150 $\mathrm{kg} \mathrm{ha}^{-1}$. According to established models plants grown under 0,50 and $150 \mathrm{~kg} \mathrm{ha}^{-1}$ of $\mathrm{K}$, reached the maximum leaf area value at $150,128.60$ and $0 \mathrm{~kg} \mathrm{ha}^{-1}$ of $\mathrm{N}$, respectively (Figure 3B).

For $\mathrm{N}$ and $\mathrm{K}$ interaction, it was verified for total leaf area an opposite tendency in treatment without $\mathrm{N}$ and $\mathrm{K}$ as a function of increasing doses of $\mathrm{K}$ and $\mathrm{N}$, respectively (Figure 3A and $3 \mathrm{~B}$ ). With additions of $\mathrm{N}$ rates, for higher doses of $\mathrm{K}\left(150 \mathrm{~kg} \mathrm{ha}^{-1}\right)$ there was a decrease in leaf area (decreasing linear model), indicating the competitive inhibition between ions. When plants received no $\mathrm{N}$ supply, additional $\mathrm{K}$ rates resulted in enhance of total leaf area (increasing linear model), suggesting no interference between ions. Laclau et al. (2008) verified in eucalyptus plants that the effect of $\mathrm{K}$ fertilization was more evident than that promoted by $\mathrm{N}$ fertilization for both mass accumulation and leaf longevity.

For the interaction between $\mathrm{N}$ and $\mathrm{K}$ a specific inverse adjustment was verified: for lower doses of $\mathrm{N}$, higher leaf area values were achieved when the plants were subjected to higher doses of $\mathrm{K}$. When the $\mathrm{N}$ rates were high, the leaf area maximization of the area was reached in condition of reduced availability of $\mathrm{K}$. The same was observed when $\mathrm{K}$ doses were fixed and analyzed in function to N (Figure 3). NurzynskaWierdak et al. (2011) described that increasing $\mathrm{N}$ and $\mathrm{K}$ doses applied to basil plants were related to alterations of EC occasioned by N-NH$H_{4}$ and $\mathrm{N}-\mathrm{NO}_{3}$ contents and $\mathrm{K}$ concentration in the substratum. This condition could result in a water availability restriction caused by reduction of osmotic potential, and in consequence, leaf area elongation could be restricted.

In conclusion, a quadratic model was designed between nutrient doses and growth, characterized by a maximizing effect of $\mathrm{N}$ and from this value $\mathrm{N}$ increasing doses were associated to decreasing values. The $\mathrm{K}$ increasing doses promoted reduction of apical dominance inducing a higher number of plagiotropic branches originating a rising linear function. The major effect of interaction between $\mathrm{N}$ and $\mathrm{K}$ doses was verified for leaf area.

\section{REFERENCES}

ALIZADEH A; ORTEZA KHOSHKHUI M; JAVIDNIA K; FIRUZI O; TAFAZOLI E; KHALIGHI A. 2010. Effects of fertilizer on yield, essential oil composition, total phenolic content and antioxidant activity in Satureja hortensis L. (Lamiaceae) cultivated in Iran. Journal of Medicinal Plants Research 4: 33-40.

BIESIADA A; KUŚ A. 2010. The effect of nitrogen fertilization and irrigation on yielding and nutritional status of sweet basil (Ocimum basilicum 1.). Acta Scientiarum Polonorum 9: 3-12.

CAMARGO MS; MELLO SC; CARMELLO QAC. 2008. Adubação nitrogenada e potássica do Aster ericoides cultivado em solo sob estufa. Horticultura Brasileira 26: 190-193.

COSTA LCB; PINTO JEBP; CASTRO EM; BERTOLUCCI SKV; CORREAA RM; REIS ES; ALVESPB; NICULAU ES. 2008. Tipos e doses de adubação orgânica no crescimento, no rendimento e na composição química do óleo essencial de elixir paregórico. Ciência Rural 38: 2173-2180.

GOLCZ A; POLITYCKA B; SEIDLERŁOŻYKOWSKA K. 2006. The effect of nitrogen fertilization and stage of plant development on the mass and quality of sweet basil leaves (Ocimum basilicum L.). Herba Polonica 52: 22-30.

González-García, JL, Rodríguez-Mendoza MN, Sánchez-García P, Osorio-Rosales B, TrejoTéllez LI, Alcántar-González G; SandovalVilla M. 2009. AMMONIUM/NITRATE RATIOS IN HYDROPONIC PRODUCTION OF AROMATIC HERBS. Acta Horticulturae 843: $123-128$

JAĆIMOVIĆ G; CRNOBARAC J; NINIĆTODOROVIĆ J, MARINKOVIĆ B; ŠTETIĆ J. 2010. The yield and morphological properties of calendula and basil in relation to nitrogen fertilization. Godina 34: 69-79.

LACLAU JP; ALMEIDA JCR; GONÇALVES JLM; SAINT-ANDRE L; VENTURA M; RANGER J; MOREIRA RM; NOUVELLON Y. 2008. Influence of nitrogen and potassium fertilization on leaf lifespan and allocation of above-ground growth in Eucalyptus plantations. Tree Physiology 29: 111-124.

MALIK AA; SURYAPANI S; AHMAD J. 2011. Chemical vs organic cultivation of medicinal and aromatic plants: the choice is clear. International Journal of Medicinal and Aromatic Plants 1: 5-13.

NURZYNSKA-WIERDAK R, ROZEK E, BOROWSKI B. 2011. Response of different basil cultivars to nitrogen and potassium fertilization: total and mineral nitrogen content in herb. Acta Scientiarum PolonorumHortorum Cultus 10: 217-232.

NGUYEN PM; KWEE EM; NIEMEYER ED. 2010. Potassium rate alters the antioxidant capacity and phenolic concentration of basil (Ocimum basilicum L.) leaves. Food Chemistry 123: 1235-1241.

POLITYCKA B, GOLCZ A. 2004.Content of chloroplast pigments and anthocyanins in the leaves of Ocimum basilicum L. depending on nitrogen doses. Folia Horticulturae 16: 23-29.

PRAKASA RAO EVS; PUTTANNA K; GANESHA RAO RS; RAMESH S. 2007. Nitrogen and potassium nutrition of French basil (Ocimum basilicum Linn.). Journal of Spices and Aromatic Crops 16: 99-105.

QI Z; HAMPTON CR; SHIN R; BARKLA BJ; WHITE PJ; SCHACHTMAN DP 2008. The high affinity $\mathrm{K}^{+}$transporter AtHAK5 plays a physiological role in plant at very low $\mathrm{K}^{+}$concentrations and provides a cesium uptake pathway in Arabidopsis. Journal of Experimental Botany 59: 595-607.

RUBIO V; BUSTOS R; IRIGOYEN ML; CARDONA-LÓPEX X; ROJAS-TRIANA M; PAZ-ARES J. 2008. Plant hormones and nutrient signaling. Plant Molecular Biology 69 361-373.

SHARAFZADEH S; ALIZADEH O. 2011. Nutrient supply and fertilization of basil. Advances in Environmental Biology 5: 956960.

SIFOLA MI; BARBIERI G. 2006. Growth, yield and essential oil content of three cultivars of basil grown under different levels of nitrogen in the field. Scientia Horticulturae 108: 408-413.

SOUZA MAA; ARAÚJO OJL; FERREIRA MA; STARK EMLM; FERNANDES MS; SOUZA SR. 2007. Produção de biomassa e óleo essencial de hortelã em hidroponia em função de nitrogênio e fósforo. Horticultura Brasileira 25: 041-048.

SZCZERBA MW; BRITTO DT; ALI SA; BALKOS KD; KRONZUCKER HJ. 2008a. NH4+-stimulated and-inhibited components of $\mathrm{K}+$ transport in rice (Oryza sativa L.). Journal of Experimental Botany 59: 34153423.

SZCZERBA MW; BRITTO DT; BALKOS KD; KRONZUCKER HJ 2008b. Alleviation of rapid, futile ammonium cycling at the plasma membrane by potassium reveals $\mathrm{K}+$-sensitive and -insensitive components of $\mathrm{NH}_{4}^{+}$transport. Journal of Experimental Botany 59: 303-313.

TSAY YF; HO CH, CHEN HY; LIN SH. 2011. Integration of nitrogen and potassium signaling. Annual Review of Plant Biology 62: 207-226.

ZHELJAZKOV VD; CANTRELL CL; EBELHAR MW; ROWE DE; COKER C. 2008. Productivity, oil content, and oil composition of sweet basil as a function of nitrogen and sulfur fertilization. HortScience 43: $1415-1422$. 